\title{
Biomass Gasification — Primary Methods for Eliminating Tar
}

\author{
Martin Lisý ${ }^{1}$, Marek Balášs ${ }^{1}$, Jiří Moskalík ${ }^{1}$, Otakar Štelcl ${ }^{1}$ \\ ${ }^{1}$ Brno University of Technology, Faculty of Mechanical Engineering, Institute of Power Engineering, Technická 2896/2, \\ 61669 Brno, Czech Republic
}

Correspondence to: lisy@fme.vutbr.cz

\begin{abstract}
This present paper deals with primary methods for reducing tar in biomass gasification, namely by feeding a natural catalyst into a fluidized bed. This method is verified using an experimental pilot plant.
\end{abstract}

Keywords: tar reduction, dolomite, catalytic reduction.

\section{Introduction}

Energy recovery from biomass is one of the most widespread and most promising ways for including renewable energy sources in the energy mix of the Czech Republic. Though the optimistic forecasts from the turn of the millennium concerning the growth of the share of RES in power generation in the Czech Republic remain unaccomplished, a host of energy technologies based on biomass have become quite advanced. One option for conventional combustion technologies is thermal gasification of biomass, and possibly also wastes. Gasification of biomass and wastes has developed progressively not only in the Czech Republic but, above all, in other countries. This technology offers a wide variety of options. There are two basic types of gasifiers: gasifiers with a fixed bed and gasifiers with a fluidized bed. The characteristics of the two types and the differences between them can be found in a number of publications [1]. These, however, are not the subject of the present paper.

Ways of using the gas that is produced form a separate topic. The ways in which the gas will be used are determined given by its quality. I, or, in other words, the requirements placed on the quality of the gas have a critical influence onin a critical manner the requirements concerning the ways that are to be used for gas cleaning.

\section{The process of gasification, and the quality of the gas that is produced}

Thermal and chemical gasification is a complex process of thermal and chemical conversion of organic matter into a low heating value gas $\left(\mathrm{CO}, \mathrm{H}_{2}, \mathrm{CH}_{4}\right.$, $\mathrm{CO}_{2}, \mathrm{~N}_{2}, \mathrm{H}_{2} \mathrm{O}$ ) consisting of a host of reactions. The process proceeds in the temperature range $750^{\circ} \mathrm{C}$ to $1000^{\circ} \mathrm{C}$. Apart from the above-mentioned combustible and inert constituents, the fuel gas that is produced also contains smaller or larger amounts of impurities. The composition and amounts of the impurities are determined by a whole host of factors (fuel composition, type of reactor, conditions in the reactor, etc.), and this has a significant impact on the consequent methods employed for gas cleaning and use. The basic contaminants contained in the gas from gasification include solid particles, alkali and nitrogen compounds, sulphur and chlorine compounds and, above all, tar.

Any gas coming from biomass gasification contains at least minimum amounts of tar, and this causes serious problems in its use. Tar is not a crucial problem for gas turbines, because there are high temperatures and the tar is combusted in the chamber. If the tar assumes the form of fumes, there are no limits on the amounts [2], but if there is condensation, the maximum amounts of tar range from $0 \mathrm{ppm}$ to $0.5 \mathrm{ppm}$, according to different authors [1]. If the gas is to be used in combustion engines, a limit is most frequently set in the interval between $10 \mathrm{mg} \cdot \mathrm{m}_{n}^{-3}$ and $100 \mathrm{mg} \cdot \mathrm{m}_{n}^{-3}$. In recent times, published works most frequently agree that the maximum amount of tar in the gas should be $50 \mathrm{mg} \cdot \mathrm{m}_{n}^{-3}[3]$. Engine makers usually do not give concrete values, but they make gas purity conditional on zero content of tar in the condensate.

\section{Tar reduction methods}

Tar production in wood gasification is much greater than that in coal or peat gasification and this tar, as a rule, consists of heavier and more stable aromatic substances [3]. These may partly react, producing gas black that clogs filters and valves, which is a problem particularly in the case of biomass gasification. 
This means that technologies developed for tar reduction in coal gasification need not necessarily apply to biomass gasification. Much research is therefore being carried out on reducing tar formation in biomass gasification, or, alternatively, on removing the tar effectively in order to use the fuel gas that is produced in combustion engines.

Measures aimed at reducing the tar content in gas can be classified according to various criteria, but the main measures can be categorized as primary or secondary. As it is not possible in most gasifiers to prevent tar formation via primary measures, it is necessary to remove tar by using gas-filtering lines, i.e. so-called secondary measures. There are several ways and methods for removing tar from gas. The most widely used methods involve the use of catalysts (natural and artificial) and wet methods (gas scrubbing). However, primary measures are applied within the reactor. They have the potential to boost overall energy conversion efficiency while at the same time reducing the need to remove tar from the gas outside the reactor. This can reduce investment costs and operating costs. Generally, two processes are applied: thermal decomposition with partial oxidation, and catalytic methods.

\section{Catalytic reduction of tar formation in gasifiers}

This method is based on the capacity of catalysts to decompose hydrocarbons into carbon monoxide, hydrogen, and lower hydrocarbons. In practice, two types of catalysts may be considered, one based on lime and dolomite, and the other based on nickel. In case of a primary measure, the catalyst is fed directly into the fluidized bed. Using a suitable catalyst, the tar content can be reduced, and in addition concentrations of undesirable compounds of sulphur and chlorine in the gas can also be reduced. Intense abrasion of adsorbent particles takes place in the fluidized bed, and small particles emerge with a sizeable surface and a considerable adsorption activity. In experiments carried out at various workplaces, the following materials have been most frequently used: dolomite, magnesite, limestone, and quartz sand. The most suitable material material seems to be dolomite, i.e. calcium magnesium carbonate, which is affordable and widely available. Among the available materials, dolomite shows the best ratio between effectiveness and abrasion resistance. Optimum temperature conditions range within the 800 to $900{ }^{\circ} \mathrm{C}$ interval, and the residence time is somewhere in the region of 0.3 to $0.8 \mathrm{sec}$. The activity of both dolomite and limestone grows as the proportion of $\mathrm{Ca} / \mathrm{Mg}$ increases [4]. The properties of various materials referred to as dolomite vary consider- ably according to the site of origin. This then has a crucial impact on their tar reduction activity. The catalytic activity of dolomite is considerably boosted after calcination, i.e. after the conversion of carbonates to oxides, which is accompanied by the release of $\mathrm{CO}_{2}$.

Catalysts may be applied directly to the bed in their solid state, or by way of wet spraying the feedstock [5]. If the reactor operation parameters are set appropriately, i.e. taking into account the temperatures and the proportions of fuels and catalysts, higher contents of $\mathrm{H}_{2}$ and $\mathrm{CO}$ are obtained in the gas, and this also slightly raises the heat value of the gas. [6] This method has a negative impact on the stability and the start-up of the gasification process.

\section{Experimental plant}

The Biofluid 100 atmospheric gasifier that is in operation in the laboratories of the Institute of Power Engineering (IPE) of the Faculty of Mechanical Engineering of the Brno University of Technology was used for the experimental part of our study. This is a facility with a stationary fluidized bed that can be run in both gasification and combustion modes of operation. The feedstock is supplied from a fuel storage bin equipped with a rake, and is fed by a worm conveyor with a frequency convertor to the reactor. Air compressed by a blower is brought as primary air under the reactor grate and, in addition, at two other height levels, it is brought as secondary and tertiary air. The produced fuel gas is rid of fly ash using a cyclone. The resulting gas is then burned using a burner equipped with a natural gas fired stabilizing burner with its own air supply. Ash from the reactor is discharged into a container placed under the grate. An electric air heater is installed at the blower outlet in order to be able to analyze the effect of air preheating. However, only the primary air is heated. A detailed description of the facility is given, e.g., in [4].

\section{Initial experimental conditions}

The basic parameters that had to be set included dolomite particle size, based on the volume and the velocity of the moving gas, and also the mass of the fluidized bed in the reactor in the course of its operation. As it was not feasible to establish the amount of fuel in the fluidized bed by way of a theoretical computation, it was necessary before the series of experiments to design and build a sampling line and to establish this amount experimentally. The feedstock was fed at $18 \mathrm{~kg} / \mathrm{hr}$., and the entire content of the reactor, which amounted to $600 \mathrm{ml}$, or $100 \mathrm{~g}$, was removed. 
Second, it was necessary to calculate the grain size of the input material to ensure proper fluidization in the reactor. For this, the highest and lowest (design) velocities of some $1 \mathrm{~m} \cdot \mathrm{s}^{-1}$ to $1.6 \mathrm{~m} \cdot \mathrm{s}^{-1}$ were used. This estimate is based on a calculation with the following assumptions: reactor geometry, temperature variations alongside its height, flow of primary air at standard reactor operation $\left(25 \mathrm{~m}_{n}^{3} \cdot \mathrm{h}^{-1}\right)$, and increment in gas volume along the height of the fluidized bed (linear 0 to $18.8 \mathrm{~m}_{n}^{3} \cdot \mathrm{h}^{-1}$ ). To achieve catalyst particle fluidization in the bed, velocity $1.6 \mathrm{~m} \cdot \mathrm{s}^{-1}$ was deemed to be the velocity of particle release from the fluidized bed. For this velocity, with the known parameters of the gas and the reactor, the smallest particle diameter is $0.35 \mathrm{~mm}$ (calcined dolomite was considered, as it is expected that calcination will occur in the reactor). For velocity $1.6 \mathrm{~m} \cdot \mathrm{s}^{-1}$ and with the given assumptions, the largest diameter of the particle was set to $2.7 \mathrm{~mm}$ (non-calcined dolomite was considered, as it was fed into the reactor in its natural form). During its residence in the bed, abrasion and calcination occur at the same time. The diminishing particle is assumed to leave the area having reached a size of $0.35 \mathrm{~mm}$. To make the constantly abraded particle stay in the bed as long as possible, and also due to the deviations of the simplified calculation, it was decided to use particles with grain size of $1 \mathrm{~mm}$ to $1.5 \mathrm{~mm}$.
The remaining quantity that had to be specified before launching the experiments was the quantity of catalyst that was to be applied. On the basis of a literature search and calculations that were made, the amount of dolomite to be used was set to be within the interval 0.027 to $0.035 \mathrm{~kg}_{\mathrm{dol}} \cdot \mathrm{kg}_{\text {fuel }}^{-1}$.

\section{The course and results of the experiments}

Tests were carried out during which the impact of adding dolomite to the fluidized bed was examined. Samples of gas and tars were first taken during each "clean" biomass gasification experiment. Catalyst was then added on an intermittent basis, and reference samples were taken afterwards. The samples were stored in glass and metallic sample containers. A gas composition analysis was carried out directly in the laboratory of IPE, using the PERKIN ELMER gas chromatograph (GC) with a packed column and a TCD detector. Tar sampling was performed behind a cyclone at the outlet from the insulated jacket of the reactor. The class of hydrocarbons with their boiling point exceeding that of phenol was defined as "tar". An HP6890 gas chromatograph with an HP5973 mass spectrometer, made by Agilent (USA), were used to establish the gas tar content and its composition.

Table 1: Properties and quantities of feedstock and dolomite batches

\begin{tabular}{|c|c|c|c|c|c|c|c|c|}
\hline & feedstock & $\begin{array}{c}\text { feedstock } \\
\text { humidity }\end{array}$ & $\begin{array}{c}\text { dolomite } \\
\text { grain size }\end{array}$ & $\begin{array}{c}\text { dolomite } \\
\text { batch }\end{array}$ & interval & $\begin{array}{c}\text { dolomite } \\
\text { total }\end{array}$ & $\begin{array}{c}\text { feedstock } \\
\text { quantity }\end{array}$ & $\begin{array}{c}\text { proportion } \\
\text { dol./feed. }\end{array}$ \\
\cline { 2 - 9 } & - & $\%$ & $\mathrm{~mm}$ & $\mathrm{~g}$ & $\mathrm{~min}$ & $\mathrm{~kg}$ & $\mathrm{~kg} / \mathrm{hr}$. & $\mathrm{kg}_{\text {dol }} / \mathrm{kg}_{\text {feed }}$ \\
\hline No.1 & shavings & 7 & $1-1.5$ & 200 & 15 & 1.2 & 21.6 & 0.034 \\
\hline No.2 & shavings & 7 & $1-1.5$ & 150 & 15 & 1.5 & 18 & 0.036 \\
\hline No.3 & chips & 15 & $0.5-1$ & 35 & 5 & 1.3 & 15.5 & 0.030 \\
\hline No.4 & chips & 18 & $0.5-1$ & 60 & 5 & 2.7 & 16 & 0.045 \\
\hline
\end{tabular}

Table 2: Temperature conditions during the experiments

\begin{tabular}{|c|c|c|c|c|}
\hline \multicolumn{2}{|c|}{$\begin{array}{c}\text { Average temperatures in the reactor } \\
\text { in the course of the experiments }\end{array}$} & $\begin{array}{c}\text { reactor } \\
\text { bottom }\end{array}$ & $\begin{array}{c}\text { reactor } \\
\text { centre }\end{array}$ & freeboard \\
\cline { 3 - 5 } & ${ }^{\circ} \mathrm{C}$ & ${ }^{\circ} \mathrm{C}$ & ${ }^{\circ} \mathrm{C}$ \\
\hline \multirow{2}{*}{ No.1 } & dolomite-free & 821 & 795 & 731 \\
\cline { 2 - 5 } & dolomite-doped & 810 & 770 & 730 \\
\hline \multirow{2}{*}{ No.2 } & dolomite-free & 853 & 813 & 712 \\
\cline { 2 - 5 } & dolomite-doped & 845 & 795 & 712 \\
\hline \multirow{2}{*}{ No.3 } & dolomite-free & 850 & 821 & 719 \\
\cline { 2 - 5 } & dolomite-doped & 835 & 800 & 735 \\
\hline \multirow{2}{*}{ No.4 } & dolomite-free & 849 & 827 & 730 \\
\cline { 2 - 5 } & dolomite-doped & 829 & 818 & 727 \\
\hline
\end{tabular}




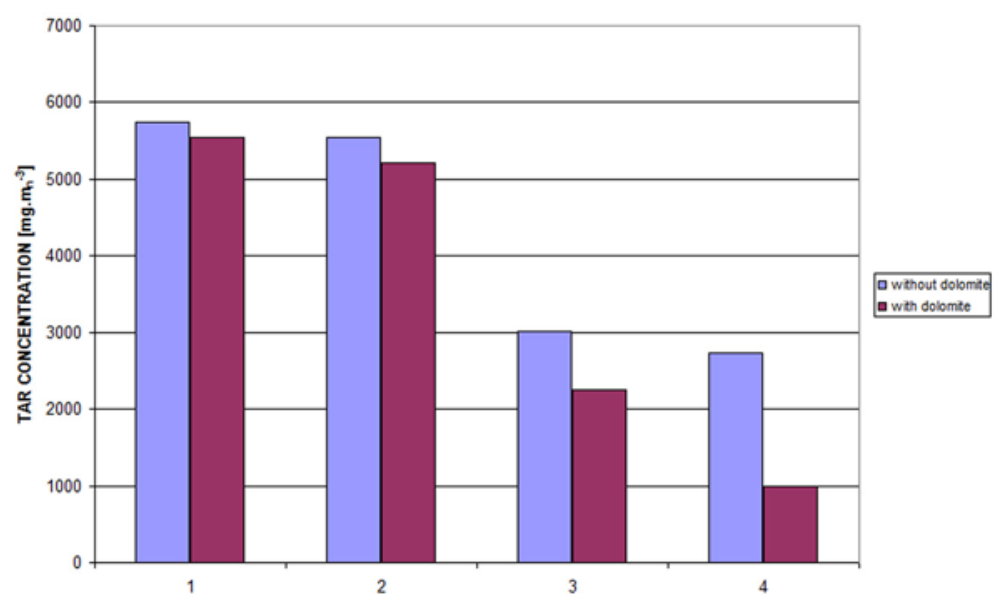

Figure 1: Comparison of tar reduction after dolomite feeding

The conditions and the results of the experiments are summarized in the following tables. This was a standard setting of the gasification process in gasifying woody biomass. When no dolomite was fed into the reactor, the temperature course and the gas composition course remained stable. Following the addition of dolomite, drops both in the reactor temperature and in $\mathrm{CO}_{2}$ content growth in the gas were observed. This is clearly due to the development of $\mathrm{CO}_{2}$ with partial or full dolomite calcination. The degree of calcination is mainly dependent on the temperature of the fluidized bed and on the content of $\mathrm{CO}_{2}$. Another reason behind the temperature drop is the onset of the reducing endothermic reactions of the tar.

\section{Evaluation of the results}

The impact of adding dolomite in the fluidized bed of the gasifier on the amounts of tar produced is clearly shown in Chart 1. Application of dolomite with grain size $1 \mathrm{~mm}$ to $1.5 \mathrm{~mm}$ into the reactor at bed temperatures between $770{ }^{\circ} \mathrm{C}$ and $810^{\circ} \mathrm{C}$ did not result in any drop in tar production. It was therefore decided to raise the temperature to the interval between $800^{\circ} \mathrm{C}$ and $840^{\circ} \mathrm{C}$. The chart shows that a moderate drop in tar content in the gas was achieved, but that this drop was insignificant. Subsequent experiments were therefore carried out at this higher temperature level. On the basis of the course of the experiment, and in particular, the changes of temperature and the changes in gas $\left(\mathrm{CO}, \mathrm{CO}_{2}\right)$ composition quantified using an on-line analyzer, it was concluded that the selected dolomite grain size was too big. It was concluded that the dolomite rests on the grate and in the bottom layer, and this prevents the necessary contact with the gas. A smaller grain size was therefore cho- sen for subsequent experiments. To curb fly ash, we opted for additions of smaller amounts of dolomite at shorter intervals. Chart 1 shows an obvious positive impact, and a drop in the amount of tar by about one quarter of the original amount. To boost this effect, it was decided to increase the amount of catalyst by about $50 \%$, and this resulted in eliminating the escape of finer particles of the catalyst. The results show that the amount of tar that was produced dropped by about $60 \%$ with this setting.

No significant variation in the makeup of the individual gas constituents was found following doping of the reactor with dolomite. Only a minor drop in the $\mathrm{CO}$ and $\mathrm{H}_{2}$ contents was encountered, together with slightly elevated concentrations of $\mathrm{CO}_{2}$ released upon dolomite calcination. The heat value of the gas that was produced ranged in the interval from 4.8 to $5.6 \mathrm{MJ} / \mathrm{m}_{n}^{3}$.

\section{Conclusions}

No fundamental changes in the composition and the content of tars in gas were found following the application of dolomite with grain sizes $1 \mathrm{~mm}$ to $1.5 \mathrm{~mm}$. These particles were probably left lying on the grate, or were fluidized in the bottom section of the reactor, and therefore failed to get in touch with the moving gas. The use of a smaller grain size, combined with the application of a large initial batch, led to tar content reduction by some 25 per cent after dolomite was applied to the bed. The dolomite bed was significantly denser, and lightweight particles became fluidized at a greater height, as is evidenced by the temperature increase in freeboard. Optimum results were then achieved by increasing the amount of dolomite to $0.045 \mathrm{~kg}_{\text {dol }} / \mathrm{kg}_{\text {fuel }}$ in experiment No. 4 .

A shortcoming of this way of reducing tar in this particular experimental facility was the low freeboard 
temperature and the stationary fluidized bed, which hampered the circulation of catalyst particles within the reactor. This was the main reason for raising the proportion of catalyst. However, it seems that the addition of dolomite in the fluidized bed may be an effective primary measure for cutting down the tar content in fuel gas. The assumption that it is not feasible to remove all tar from the gas by way of primary measures has been confirmed; nevertheless, a $60 \%$ drop in tar content brings a significant saving in investment and operating costs with secondary gas cleaning.

\section{Acknowledgement}

This paper came into being thanks to the assistance of Specific Research project FSI-S-11-7 Selected Components of Trigeneration Processes provided by Faculty of Mechanical Engineering, Brno University of Technology.

\section{References}

[1] Najser, J.: Zplyňování dřeva pro kogeneraci. Disertační práce, TU-VŠB Ostrava, 2009.

[2] Milne, T. A., Evans, R. J, Abatzoglou, N.: Biomass Gasifier "Tars": Their Nature, Formation and Conversion, NREL/TP-570-25357, Colorado, USA, 1998.

[3] Skoblia, S.: Úprava složení plynu ze zplyñování biomasy. Diser. práce. Praha: VŠCHT, 2004.

[4] Lisý, M.: Čištění energoplynu z biomasy v katalytickém vysokoteplotním filtru. Disertační práce, VUT FSI v Brně, 2009.

[5] Sutton, D., et. al.: Review of literature on catalysts for biomass gasification, Fuel Processing Technology, 2001, 73, 155-173.

[6] Perez, P., Aznar, M. P., Caballero, A. J., Gill, J., Martin, J. A., Corella, J.: Hot Gas Cleaning and Upgrading with a Calcined Dolomite Located Downstream a Biomass Fluidized Bed Gasifier Operating with Steam-Oxygen Mixtures. Energy Fuels, 1997, 11, 1194. 